\title{
The effects of temperature on the growth rate and nitrogen content of invasive Gracilaria vermiculophylla and native Gracilaria tikvahiae from Long Island Sound, USA
}

\author{
Leah Gorman ${ }^{1}$, George P. Kraemer ${ }^{1}$, Charles Yarish ${ }^{2}$, Sung Min Boo ${ }^{3}$ and Jang K. Kim ${ }^{4,5, *}$ \\ ${ }^{1}$ Department of Environmental Studies, Purchase College, 735 Anderson Hill Road, Purchase, NY 10577, USA \\ ${ }^{2}$ Department of Ecology and Evolutionary Biology, University of Connecticut-Stamford, 1 University Place, Stamford, \\ CT 06901, USA \\ ${ }^{3}$ Department of Biology, Chungnam National University, Daejeon 34134, Korea \\ ${ }^{4}$ Department of Marine Science, School of Natural Sciences, Incheon National University, Incheon 22012, Korea \\ ${ }^{5}$ Department of Marine Sciences, University of Connecticut-Stamford, 1 University Place, Stamford, CT 06901, USA
}

\begin{abstract}
The red alga Gracilaria vermiculophylla, a species native to the waters of Korea and Japan, has invaded marine coastal areas of Europe and the Americas, thriving in conditions that differ from those of its native habitat. In recent years, G. vermiculophylla has been discovered in the Long Island Sound (LIS) estuary growing alongside the native congener Gracilaria tikvahiae. The goal of this study was to determine whether the two strains of G. vermiculophylla from different regions of the world have evolved genetic differences (i.e., ecotypic differentiation) or if the physiological performance of the strains simply reflects phenotypic plasticity. Two strains of G. vermiculophylla (isolated in Korea and LIS) and a strain of the LIS native G. tikvahiae were grown for four weeks under temperatures ranging from 20 to $34^{\circ} \mathrm{C}$ using a temperature gradient table (all other environmental conditions were kept constant). At the end of each week, wet weight of each sample was recorded, and thalli were reduced to the original stocking density of $1 \mathrm{~g} \mathrm{~L}^{-1}$ (excess biomass was preserved for tissue carbon and nitrogen analysis). Generally, the growth rates of Korean G. vermiculophylla $>$ LIS G. vermiculophylla $>$ G. tikvahiae. After one week of growth G. tikvahiae grew 9.1, 12.0, 9.4, and $0.2 \% \mathrm{~d}^{-1}$, at temperatures of $20,24,29$, and $34^{\circ} \mathrm{C}$, respectively, while G. vermiculophylla (LIS) grew 6.6, 6.2, 5.7, and $3.6 \% \mathrm{~d}^{-1}$. G. vermiculophylla (Korea) grew 15.4, 22.9, 23.2, and $10.1 \% \mathrm{~d}^{-1}$, much higher than the two strains currently inhabiting the LIS. On average, the LIS G. vermiculophylla strain contained 4-5\% DW N, while the Korean strain and G. tikvahiae had more modest levels of 2-3\% N DW. However, tissue $\mathrm{N}$ content declined as temperature increased in LIS and Korean G. vermiculophylla. The non-native haplotype may have evolved genetic differences resulting in lower growth capacity while concentrating significantly more nitrogen, giving the non-native a competitive advantage.
\end{abstract}

Key Words: Gracilaria tikvahiae; G. vermiculophylla; invasion; Long Island Sound; temperature

\section{INTRODUCTION}

The entrance of non-native species into an ecosystem, a problem of anthropogenic origin, can cause a plethora of economic and environmental harms, threatening the native biodiversity and altering the flow of energy and
(9) $\$$ This is an Open Access article distributed under the terms of the Creative Commons Attribution Non-Commercial License (http://creativecommons.org/licenses/by-nc/3.0/) which permits unrestricted non-commercial use, distribution, and reproduction in any medium, provided the original work is properly cited.
Received July 1, 2016, Accepted January 30, 2017

* Corresponding Author

E-mail: jang.kim@inu.ac.kr

Tel: +82-32-835-8877, Fax: +82-32-835-0806 
material within the ecosystem (Sakai et al. 2001). Globalization of international trade has facilitated numerous marine invasions when species are unintentionally transported as epiphytes and epizoans on ships and in ballast water (Carlton 2001, Cohen et al. 2001, Johnson and Chapman 2007). In addition to the presence of welltrafficked shipping ports, coastal estuarine systems are invaded to a greater degree than other marine systems as a result of physical disturbance (Anderson 2007) and lower native diversity (e.g., Stachowicz et al. 1999).

Invasive species often cause ecological harm as a result of their broad phenotypic plasticity, generalist habits, and copious reproductive output (Sakai et al. 2001). These characteristics allow them to adapt to the new habitat and establish a population, and disperse. The red alga Gracilaria vermiculophylla, a native of Asia, has invaded coastal marine ecosystems within Europe and the Americas, establishing populations across a range of environmental conditions (Abreu et al. 2011b, Nettleton et al. 2013). G. vermiculophylla grows well in muddy, softbottom environments (Abreu et al. 2011b), under a wide range of temperatures (Kim et al. 2016), and exhibits high stress resistance (Kim et al. 2010). These characteristics have allowed G. vermiculophylla to successfully invade habitats characterized by temperatures unlike those of its native range (warm temperate to subtropical regions of the northwestern Pacific, including areas of Korea, China and Japan) (Tseng and Xia 1999). In 2000, G. vermiculophylla was detected on the coast of North Carolina (Freshwater et al. 2006). Since then, the seaweed has been identified in an increasingly wide area along the Pacific coast from Baja California to British Columbia (Kim et al. 2010) and along Georgia and New England coastal regions ranging from North Carolina to Greenland, New Hampshire (Byers et al. 2012, Nettleton et al. 2013).

Historically, successful invasive seaweeds such as Caulerpa taxifolia and Codium fragile subsp. tomentosoides have experienced genetic bottlenecks in areas of invasion (Johnson and Chapman 2007). Genetic studies comparing strains of G. vermiculophylla inhabiting nonnative regions with strains growing in native Korean regions have found extreme genetic homogeneity within the non-native range and high heterogeneity among Korean strains (Kim et al. 2010). Kim et al. (2010) concluded that $G$. vermiculophylla is therefore demonstrating patterns expected of highly invasive seaweeds and further, that introductions are likely to occur as single event phenomena. However, Gulbransen et al. (2012) evaluated the same species using a more extensive sampling design and found higher coxl haplotype diversity. This result suggest multiple introductions from multiple geographic sources.

Gracilaria tikvahiae is a native of Long Island Sound (LIS) (Schneider et al. 1979). Its morphology is similar to that of G. vermiculophylla. In recent years, G. tikvahiae and G. vermiculophylla have been found growing alongside each other within the coastal areas of the LIS (Nettleton et al. 2013). According to previous research, both species exhibit similar patterns of growth (Abreu et al. 2011c, Kim and Yarish 2014). The two Gracilaria species compete for the same resources within the LIS ecosystem. However, as G. vermiculophylla has invaded areas of Europe and North America, some speculate that the seaweed could outcompete native G. tikvahiae (Nettleton et al. 2013, Lopez et al. 2014, Kim et al. 2016). Due to the location of LIS along a biogeographic boundary, this ecosystem is characterized by biota with collectively broad temperature tolerances. Many seaweed species of cool temperate affinities in the LIS are at the southernmost limit of tolerance, while warm temperate species also inhabit LIS (Lüning 1990, Lopez et al. 2014). A non-native warm temperate species such as G. vermiculophylla could outcompete cool temperature species persisting in their southern limit.

Globally, temperatures are rising, with the LIS no exception. In recent years, summer maximum seawater temperatures were as high as $23.8^{\circ} \mathrm{C}$ in LIS (Johnson et al. 2014, Kim et al. 2014, National Centers for Environmental Information 2015). Anthropogenic climate change has driven temperature increases of ca. $0.6^{\circ} \mathrm{C}$ per decade in LIS over the past 25 years (Keser et al. 2003), with a projected increase of an additional $3^{\circ} \mathrm{C}$ within the 21 st century (Intergovernmental Panel on Climate Change 2014). This increase may be detrimental to native biota of the LIS that are persisting at their southern limit of distribution. Tropical and sub-tropical non-native species are likely to thrive in what are currently temperate regions as temperatures increase, especially during the warmer winter months (Stachowicz et al. 2002). If G. vermiculophylla out-competes the LIS native as temperatures rise, the seaweed has the potential to alter the LIS ecosystem.

The goal of this experiment was to determine whether the two strains of G. vermiculophylla from different regions of the world have evolved genetic differences (i.e., ecotypic differentiation) or if the physiological performance of the strains simply reflects phenotypic plasticity. A second goal was to understand the effect of elevated temperature on the growth and physiology of Gracilaria, a genus of rhodophyte proposed for aquaculture and nitrogen bioremediation (Kim et al. 2014). Toward these goals, growth rates and tissue nitrogen and carbon con- 
tents of two strains of G. vermiculophylla (Korea, LIS) were compared with a strain of the LIS native G. tikvahiae cultured at four temperatures.

\section{MATERIALS AND METHODS}

Three different strains of seaweed were grown at the same time and monitored for four weeks at the University of Connecticut. The LIS strain of G. vermiculophylla (G-NY-ST4) was originally collected from Rye, NY in July 2010. G. tikvahiae (G-RI-G1) was derived from a carpospores collected in April 2010, Potter Pond, South Kingston, RI. The Korean strain of G. vermiculophylla (GVKR-ST3) was provided by prof. S. M. Boo's Laboratory at Chungnam National University, Korea. This strain was originally collected from Juncheon, Mukho, Korea. Before the experiments began, this Korean strain was cultured at the Seaweed Biotechnology Laboratory, University of Connecticut at Stamford for more than 2 years. The waste from the cultures was discarded properly to avoid any potential issues to the local waters. All the species were previously identified using coxl gene (see Kim et al. 2010 and Nettleton et al. 2013 for details).

Using the temperature gradient table at the University of Connecticut (Stamford, CT, USA), four cultures of each strain were placed under temperature conditions of ca. 20, 24, 29, and $34^{\circ} \mathrm{C}$ (Yarish and Edwards 1982). Four replicates of each temperature, ca. $0.3 \mathrm{~g}$ FW of each sample, were placed in $350 \mathrm{~mL}$ deep petri storage dishes filled with $300 \mathrm{~mL}$ of von Stosch's enrichment, germanium dioxide treated seawater to inhibit diatom growth (Lewin 1966). Samples were grown under $12: 12 \mathrm{~L}: \mathrm{D}$ at $150 \mu \mathrm{mol}$ photons $\mathrm{m}^{-2} \mathrm{~s}^{-1}$ on the gradient table and connected to a single aeration system through individual tubing. Cultures were grown under these constant conditions for four weeks, cutting back biomass to the initial stocking density, $1.0 \mathrm{~g} \mathrm{~L}^{-1}$, once a week and replacing the von Stosch enriched seawater growth medium on the first and fourth days of each week. The position of each sample on each temperature row of the gradient table was randomized at the outset of the experiment and after each water change.

Each sample was blotted with paper toweling to remove superficial water and then weighed for a weekly final biomass. Excess biomass beyond the stocking density was collected and placed in a drying oven $\left(\right.$ ca. $60^{\circ} \mathrm{C}$ ) for dry weight measurement and elemental analysis using a CHN analyzer (Series II, CHNS/O 2400 Analyzer; Perkin Elmer Analytical Division of E.G. \& G., Wellesley, MA, USA). At the end of each of 4 weeks, wet biomass was measured to determine daily growth rate using the following equation:

$$
\text { Specific growth rate }\left(\mathrm{SGR}, \mathrm{d}^{-1}\right)=\frac{\operatorname{In} S_{2}-\operatorname{In} S_{1}}{T_{2}-T_{1}}
$$

, where $S_{1}$ and $S_{2}$ are the fresh weight at days $T_{1}$ and $T_{2}$, respectively. Samples that were bleached were removed from the experiment and saved for CHN analysis. Samples from cultures having a growth rate near zero could not be collected for $\mathrm{CHN}$ analysis. Rather, these cultures were weighed and allowed to continue growth. Dried tissue samples were powdered using an industrial grinder (MM200 Grinder; Retsch, Haan, Germany) and prepared for carbon $(\mathrm{C})$ and nitrogen $(\mathrm{N})$ measurement using a CHN analyzer (Perkin Elmer Analytical Division of E.G. \& $\mathrm{G)}$.

Specific growth rate $\left(\mathrm{d}^{-1}\right)$ and $\%$ tissue nitrogen and carbon were calculated for each replicate in all treatments each week. In general, growth rates did not remain constant, though appeared to stabilize for most treatments by the end of the four-week experiment. For this reason, we focused most attention on the end point (i.e., week 4) data. Data were tested for normality and homogeneity of variance. Since several treatment combinations had significantly greater variance, all data was transformed prior to analysis (ln transformation for tissue composition, arcsin transformation for the proportional biomass increase). Data were analyzed within each temperature using a one-way ANOVA model with Gracilaria strain as the treatment factor. When ANOVA test indicated a significant treatment effect (i.e., when strains differed within a temperature), a Fisher least significant difference test was used to determine which treatments differed. The effect of temperature on carbon and nitrogen content of tissues was analyzed using linear regression.

\section{RESULTS}

Overall, the LIS strain of G. vermiculophylla grew at rates more similar to those of G. tikvahiae than to those of the Korean strain of G. vermiculophylla (Fig. 1). For each temperature, the Korean strain grew at a consistently higher rate than the LIS strain and G. tikvahiae. After one week, in the 24 and $29^{\circ} \mathrm{C}$ treatments the Korean strain of G. vermiculophylla grew at rates of 0.229 and $0.232 \mathrm{~d}^{-1}$, respectively. Under the same conditions in the first week the LIS strain grew at 0.062 and $0.057 \mathrm{~d}^{-1}$ and G. tikvahiae grew at 0.120 and $0.094 \mathrm{~d}^{-1}$ (Fig. 1). For 20, 24, and $29^{\circ} \mathrm{C}$ treatments, all strains displayed a general decline in 


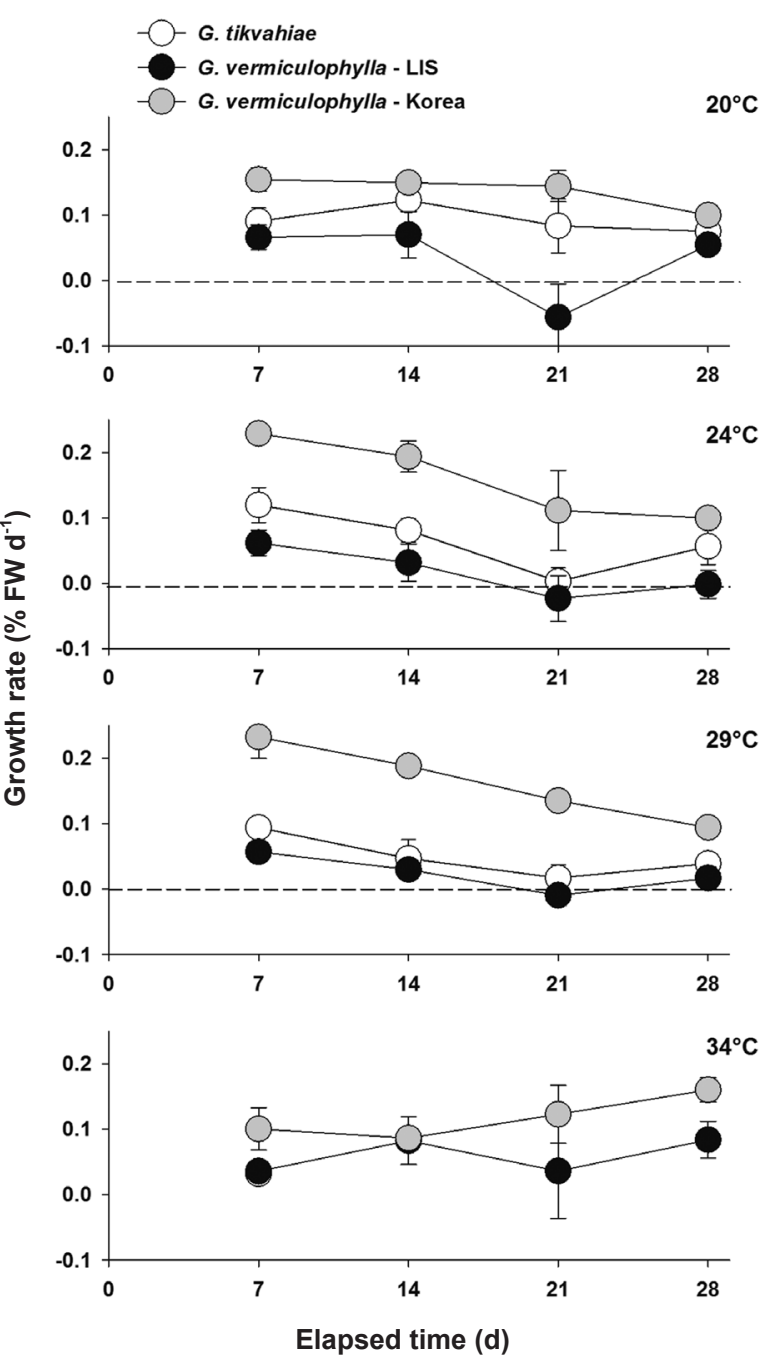

Fig. 1. Average weekly specific growth rates $\left(d^{-1}\right)$ at $20,24,29$, and $34^{\circ} \mathrm{C}$. Error bars (standard deviation) are not visible within some plots since standard deviation are smaller than the symbols. Gracilaria tikvahiae at $34^{\circ} \mathrm{C}$ is not displayed past week 1 as no replicates survived under this condition. LIS, Long Island Sound.

growth rate over time. However, at $34^{\circ} \mathrm{C}$, the growth rate of the Korean G. vermiculophylla strain increased slightly, though significantly from $0.101-0.160 \mathrm{~d}^{-1}\left(\mathrm{~F}_{1,15}=7.60, \mathrm{p}=\right.$ 0.015). G. tikvahiae at $34^{\circ} \mathrm{C}$ bleached within the first week and were therefore removed from growth experimentation. By the end of the second week, one replicate of $G$. tikvahiae at $29^{\circ} \mathrm{C}$ bleached and consequently was also removed (Fig. 1).

At the start of the experiment, the LIS strain of G. vermiculophylla had highest tissue $\mathrm{N}$ levels (avg $=3.94 \% \mathrm{~N}$ DW) (Fig. 2). Tissue N contents of G. tikvahiae and the Korean strain of G. vermiculophylla were 43 and $48 \%$ less (2.26 and $2.05 \% \mathrm{~N}$ DW, respectively) at the start. For each

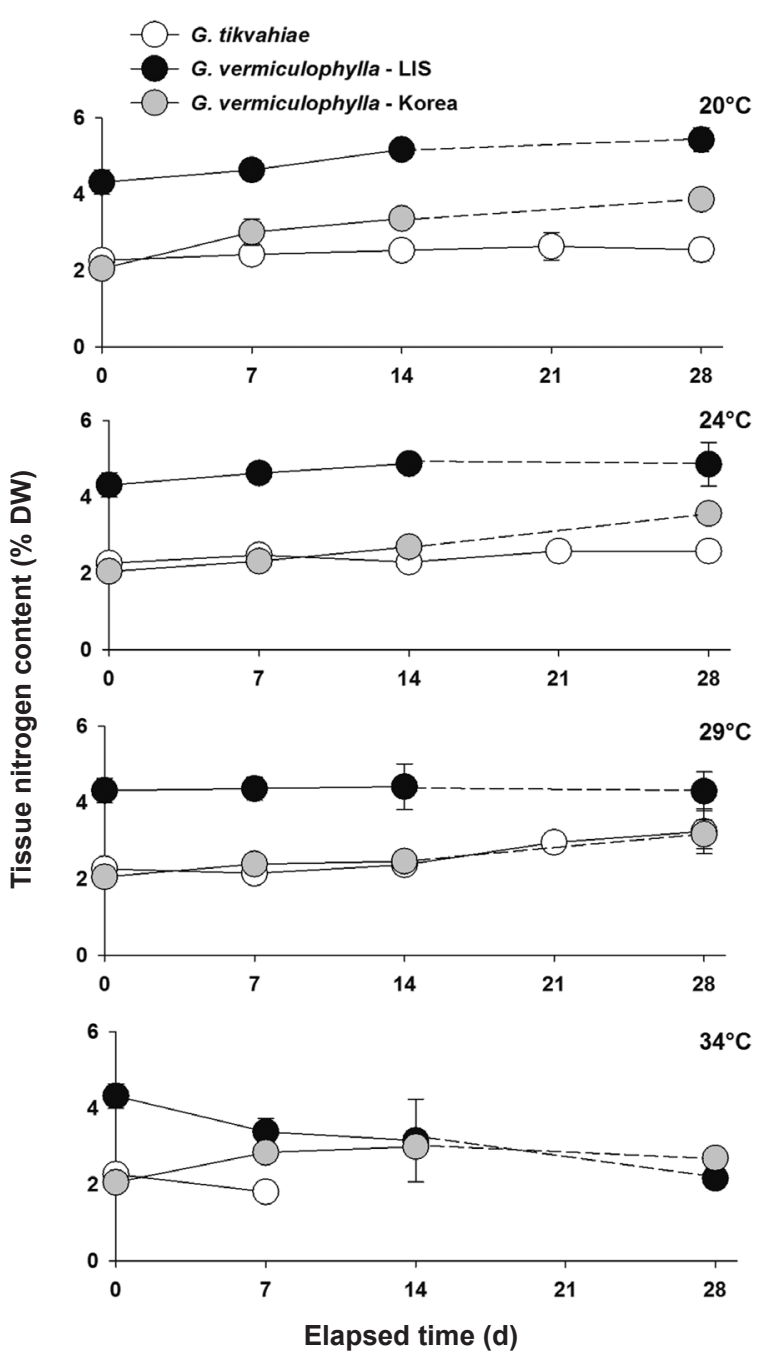

Fig. 2. Average percent tissue nitrogen in each dried sample after each of four weeks for each strain at 20,24, 29, and $34^{\circ} \mathrm{C}$. Dotted lines were places in lieu of week 3 measurements for Gracilaria. vermiculophylla strains which could not be made. Error bars (standard deviation) are not visible within some plots since standard deviation are smaller than the symbols. Gracilaria tikvahiae at $34^{\circ} \mathrm{C}$ is not displayed after week 1 as no replicates survived under this condition. LIS, Long Island Sound.

temperature treatment, tissue of the LIS strain of G. vermiculophylla had consistently higher levels of $\mathrm{N}$ than did the Korean strain and the LIS native G. tikvahiae, with one exception in the $34^{\circ} \mathrm{C}$ treatment in week 4 wherein the Korean strain had a higher average concentration (Fig. 2). The LIS strain exhibited nitrogen levels ca. 4-5\% N DW whereas the Korean strain and G. tikvahiae produced tissue with 2-3\% N, DW (Fig. 2). The tissue N content of G. tikvahiae remained relatively constant over the fourweek period.

After four weeks in culture, the ANOVA showed sig- 


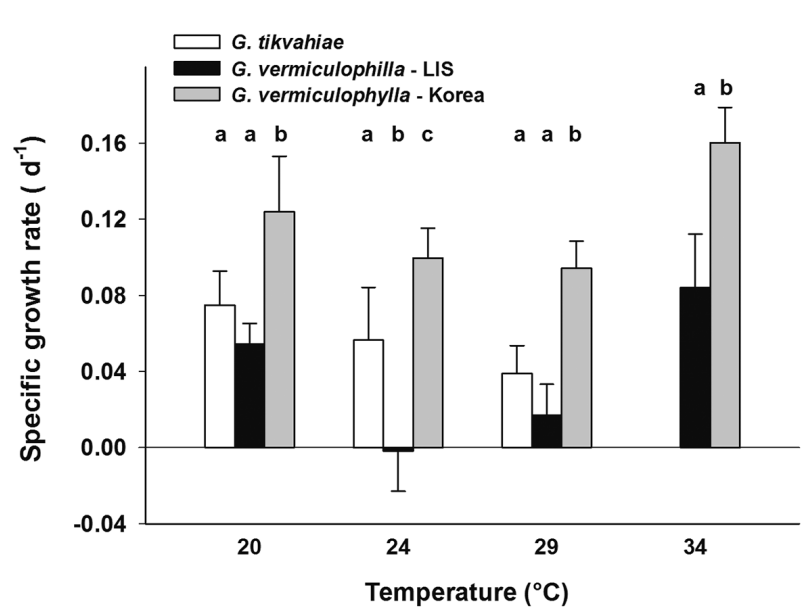

Fig. 3. Average specific growth rate $\left(\mathrm{d}^{-1}\right)$ during week 4 for each strain under temperature conditions $20,24,29$, and $34^{\circ} \mathrm{C}$. Error bars are standard deviations. Letters above bars denote results of a Fisher least significant difference test comparing the strains within each temperature treatment after an ANOVA revealed significant difference among strains for 24,29 , and $34^{\circ} \mathrm{C}$ temperature treatments. LIS, Long Island Sound.

nificant differences among strains for each temperature treatment (Table 1). The specific growth rate of the Korean strain of G. vermiculophylla was greater than that of the other strains under all four culture temperatures (Fig. 3). The difference between tissue $\mathrm{N}$ concentrations of each strain was significant for every temperature with the exception of the $29^{\circ} \mathrm{C}$ treatment. In the $29^{\circ} \mathrm{C}$ during week 4, the N concentrations of the Korean strain of $G$. vermiculophylla and G. tikvahiae were not significantly different. The tissue N content of both strains of G. vermiculophylla was influenced by culture temperature (Table 1, Fig. 4); as culture temperature increased, tissue $\mathrm{N}$ decreased significantly for LIS G. vermiculophylla $\left(\mathrm{F}_{1,14}\right.$ $=68.3, \mathrm{p}<0.001)$ and Korean G. vermiculophylla $\left(\mathrm{F}_{1,14}=\right.$ $56.5, \mathrm{p}<0.001)$. This decrease in tissue $\mathrm{N}$ from $20-34^{\circ} \mathrm{C}$ was greater for the LIS vermiculophylla strain (60\% drop) than for the Korean strain ( $30 \%$ drop). The four-week N content of G. tikvahiae was not influenced significantly by culture temperature $\left(\mathrm{F}_{1,14}=5.18, \mathrm{p}=0.057\right)$.

At the start of the experiment, the LIS strain of G. vermiculophylla had highest tissue C levels (avg $=34.7 \%$ DW), while those of the Korean strain of G. vermiculophylla and G. tikvahiae were 10 and $31 \%$ less (31.2 and $23.9 \%$ C DW, respectively) at the start. After four weeks in culture, the Gracilaria strains differed in carbon content, generally ranking G. vermiculophylla - LIS > G. tikvahiae, G. vermiculophylla - Korea (Table 1, Fig. 5). Linear regression analysis of tissue carbon content on temperature

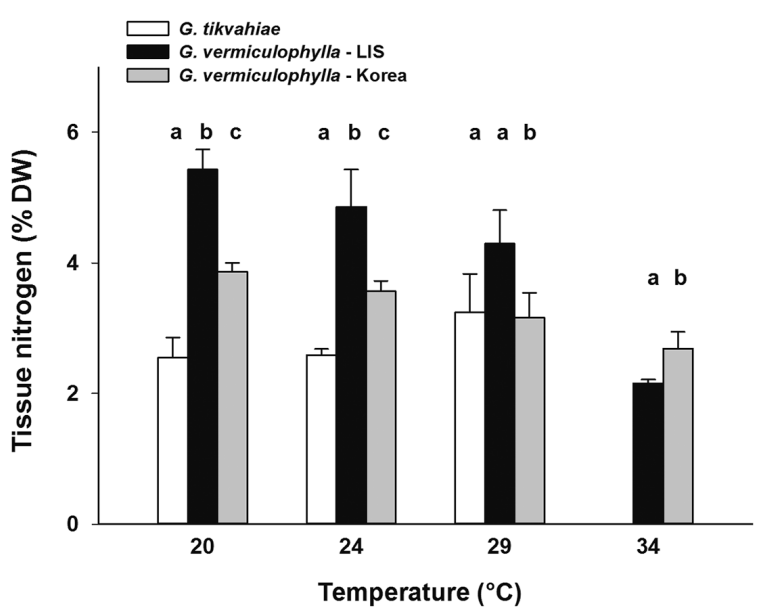

Fig. 4. Average percent tissue nitrogen during week 4 for each strain under temperature conditions $20,24,29$, and $34^{\circ} \mathrm{C}$. Error bars are standard deviations. Letters above bars denote results of a Fisher least significant difference test comparing the strains within each temperature treatment after an ANOVA revealed significant difference among strains. LIS, Long Island Sound.

Table 1. Results of analysis of variance of initial (tissue N, C) and week four (endpoint; tissue N, C, growth rate) data

\begin{tabular}{clc}
\hline & ANOVA F & p-value \\
\hline Growth rate & & \\
$20^{\circ} \mathrm{C}$ & $\mathrm{F}_{2,10}=10.5$ & 0.004 \\
$24^{\circ} \mathrm{C}$ & $\mathrm{F}_{2,10}=15.7$ & 0.001 \\
$29^{\circ} \mathrm{C}$ & $\mathrm{F}_{1,6}=37.9$ & $<0.001$ \\
$34^{\circ} \mathrm{C}$ & $\mathrm{F}_{1,6}=15.4$ & 0.008 \\
Tissue N & & \\
Initial & $\mathrm{F}_{2,12}=193$ & $<0.001$ \\
$20^{\circ} \mathrm{C}$ & $\mathrm{F}_{2,11}=91.0$ & $<0.001$ \\
$24^{\circ} \mathrm{C}$ & $\mathrm{F}_{2,10}=58.5$ & $<0.001$ \\
$29^{\circ} \mathrm{C}$ & $\mathrm{F}_{2,10}=5.75$ & 0.028 \\
$34^{\circ} \mathrm{C}$ & $\mathrm{F}_{1,6}=18.0$ & 0.006 \\
Tissue C & & \\
Initial & $\mathrm{F}_{2,12}=547$ & $<0.001$ \\
$20^{\circ} \mathrm{C}$ & $\mathrm{F}_{2,11}=61.9$ & $<0.001$ \\
$24^{\circ} \mathrm{C}$ & $\mathrm{F}_{2,10}=70.9$ & 0.001 \\
$29^{\circ} \mathrm{C}$ & $\mathrm{F}_{2,10}=75.2$ & $<0.001$ \\
$34^{\circ} \mathrm{C}$ & $\mathrm{F}_{1,6}=12.3$ & 0.013 \\
Tissue $\mathrm{C}: \mathrm{N}$ & $\mathrm{F}_{2,12}=248$ & \\
Initial & $\mathrm{F}_{2,11}=36.6$ & $<0.001$ \\
$20^{\circ} \mathrm{C}$ & $\mathrm{F}_{2,10}=20.5$ & 0.001 \\
$24^{\circ} \mathrm{C}$ & $\mathrm{F}_{2,10}=2.54$ & $\mathrm{NS}$ \\
$29^{\circ} \mathrm{C}$ & $\mathrm{F}_{1,6}=28.7$ & 0.002 \\
$34^{\circ} \mathrm{C}$ & $\mathrm{C}^{\circ}$ &
\end{tabular}

Since in some cases, variances differed among treatments, data were transformed prior to ANOVA, to meet the assumption of homoscedasticity (growth rate, and tissue $\mathrm{N}$ and $\mathrm{C}$ data were arcsine- and In-transformed, respectively). In all cases, results are from one-way ANOVA within each temperature, with Gracilaria strain the tested factor. The power of the tests all exceeded 0.89 , except for tissue $\mathrm{N}$ and $\mathrm{C}: \mathrm{N}$ at $29^{\circ} \mathrm{C}$ (power $=0.62$ and 0.23 , respectively).

NS, not significant. 


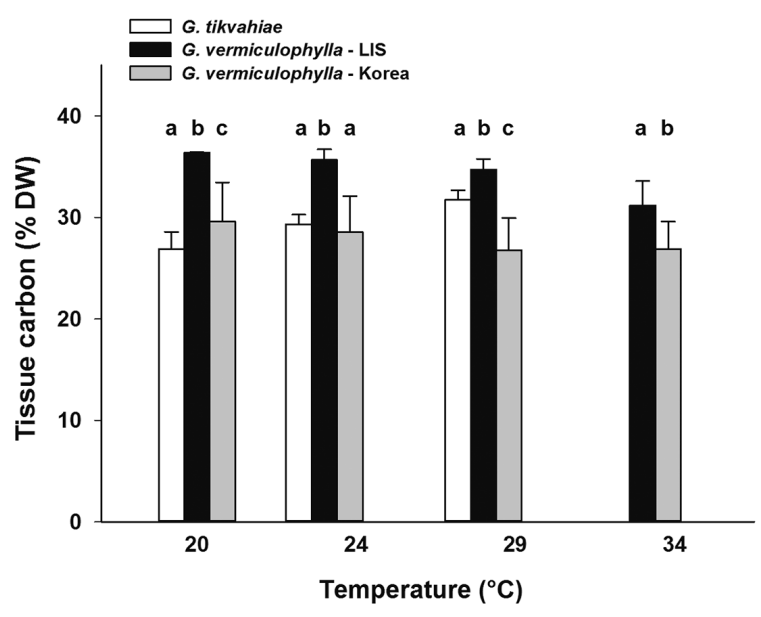

Fig. 5. Average percent tissue carbon during week 4 for each strain under temperature conditions $20,24,29$, and $34^{\circ} \mathrm{C}$. Error bars are standard deviations. Letters above bars denote results of a Fisher least significant difference test comparing the strains within each temperature treatment after an ANOVA on In-transformed data revealed significant difference among strains. LIS, Long Island Sound.

revealed that the strains differed in their response to temperature; as culture temperature increased, the carbon content of G. tikvahiae increased significantly $\left(\mathrm{F}_{1,8}=30.0\right.$, $\mathrm{p}<0.001$ ), while the tissue $\mathrm{C}$ content of both strains of $G$. vermiculophylla (i.e., LIS and Korea) declined $\left(\mathrm{F}_{1,14}=26.7\right.$, $\mathrm{p}<0.001$ and $\mathrm{F}_{1,14}=20.5, \mathrm{p}<0.001$, respectively). After four weeks, the tissue $\mathrm{C}: \mathrm{N}$ ratio also varied (Table 1, Fig. 6). The $\mathrm{C}: \mathrm{N}$ ratio of G. tikvahiae did not vary as a function of temperature $\left(\mathrm{F}_{1,7}=0.34, \mathrm{p}=0.57\right)$, while the ratio for both G. vermiculophylla - LIS and G. vermiculophylla - Korea increased significantly with temperature $\left(\mathrm{F}_{1,14}=\right.$ 41.2, $\mathrm{p}<0.001$ and $\mathrm{F}_{1,14}=24.6, \mathrm{p}<0.001$, respectively).

\section{DISCUSSION}

The measurements of growth rate and tissue $\mathrm{N}$ concentration suggest that the LIS strain of G. vermiculophylla either has different physiological characteristics or has evolved differences from the strain obtained from its native range. Growth of the Korean strain of G. vermiculophylla was generally faster than the invasive LIS strain of the same species. However, the two G. vermiculophylla strains also concentrated different amounts of nitrogen. The invasive LIS strain concentrated larger amounts of nitrogen $(4-5 \%$ N DW) than the Korean strain (2-3\% N DW) at every measurement point. Statistical analyses of week 4 data for the temperatures that currently represent LIS

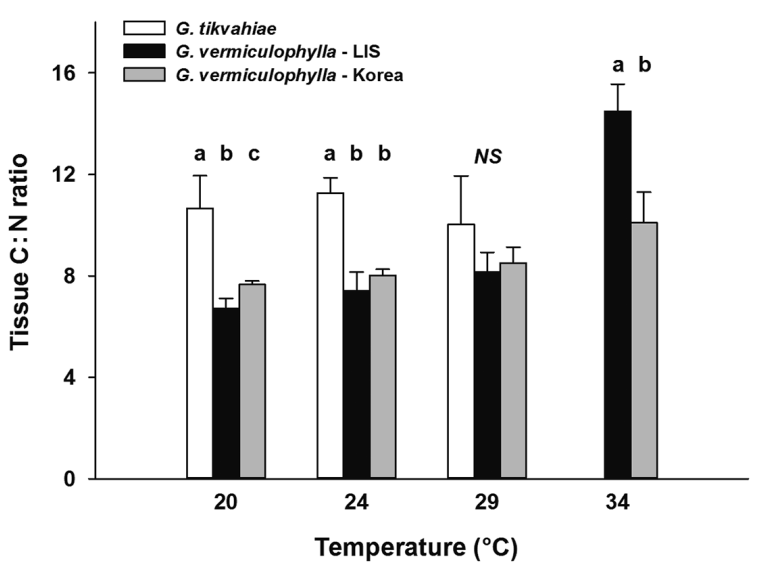

Fig. 6. Average tissue carbon : nitrogen ratio during week 4 for each strain under temperature conditions $20,24,29$, and $34^{\circ} \mathrm{C}$. Error bars are standard deviations. Letters above bars denote results of a Fisher least significant difference test comparing the strains within each temperature treatment after an ANOVA on In-transformed data revealed significant difference among strains. LIS, Long Island Sound; $N S$, not significant.

conditions $\left(20,24\right.$, and $\left.29^{\circ} \mathrm{C}\right)$ demonstrated a significant difference between the two G. vermiculophylla strains, with the Korean strain growing 4.6-fold faster, while accumulating ca. $30 \%$ less $\mathrm{N}$ than the LIS strain.

A recent study reported the prostaglandin $\mathrm{E}_{2}$ concentration in the introduced G. vermiculophylla in Europe and North America was much higher than that in the native population in Asia (Hammann et al. 2016). This prostaglandin is a toxic compound that provides protection against animal consumers (Weinberger et al. 2013). Interestingly, another study reported three haplotypes of the mitochondrial cytochrome oxidase subunit I (coxl) gene in G. vermiculophylla collected in Europe and Americas, with only one shared among all regions (Kim et al. 2010). The shared haplotype was present in all introduced populations in Europe and Americas, and in native populations in Asia. These results together indicate that some level of ecotypic adaptation has occurred during the colonization and expansion of this species in the Atlantic Oceans.

The invasive LIS G. vermiculophylla strain tended to grow at rates that were more similar to those of the native G. tikvahiae than to that of G. vermiculophylla from its native Korean range. However, several factors suggest that G. vermiculophylla may out-compete the native $G$. tikvahiae. North Atlantic seaweeds tend to tolerate a narrow range of temperatures (Breeman 1988). G. tikvahiae appears to fit within this category. The seaweed survived 
under the 20 and $24^{\circ} \mathrm{C}$ treatments, temperatures representative of current summer conditions in the LIS (National Centers for Environmental Information 2015). One replicate did not survive past one week of growth in $29^{\circ} \mathrm{C}$ and none survived in the $34^{\circ} \mathrm{C}$, suggesting that $29^{\circ} \mathrm{C}$ represents the approximate upper temperature limit for $G$. tikvahiae. G. vermiculophylla has a wider temperature tolerance as both G. vermiculophylla strains remained healthy under 29 and $34^{\circ} \mathrm{C}$. In addition, G. vermiculophyl$l a$ is able to grow at low temperature. This alga grew at $<1^{\circ} \mathrm{C}$ in LIS during late winter and had little problem surviving with its perennating disc (Yarish et al. 1984, 1986, Abreu et al. 2011b, Kim et al. 2015, 2016). This provides a longer growing season than the native since the native begins its growth of uprights at $15^{\circ} \mathrm{C}$ and above (Yarish et al. 1984, 1986).

As temperatures increase, results from the present study suggest that G. vermiculophylla will grow faster than G. tikvahiae. Additionally, increasing winter temperatures have been demonstrated to benefit non-native species from sub-tropical and warm temperate regions. In the Northern Atlantic, the most pronounced temperature increases as a result of climate change are seen in the winter months. During warm winters, non-native species from warmer environments experience high recruitment rates (Stachowicz et al. 2002). A synergism between anthropogenic climate change and non-native species introduction creates negative changes to native community dynamics (Williams and Grosholz 2008).

Though the LIS invader G. vermiculophylla grew at similar rates as the native G. tikvahiae, the invasive strain concentrated significantly more nitrogen, a characteristic that may give it a competitive advantage (Nettleton et al. 2013, Lopez et al. 2014). The strain may have altered its life history strategy in the new environment, focusing on storing nitrogen when available. Past studies have shown high nitrogen concentrations in G. vermiculophylla during winter months and low tissue concentrations during summer months as a result of limited nitrogen availability (Abreu et al. 2011a). The greater stored nitrogen in the invasive strain could be used to extend the period of active growth during summer months of optimal light and temperature conditions, but limited nitrogen. The ability to store excess nitrogen facilitates competitive success of the non-native species (Abreu et al. 2011a). Additionally, higher culture temperature resulted in reduced tissue $\mathrm{N}$ concentration (and increased C : N ratio) in the two $G$. vermiculophylla strains. This may be analogous to the Neish effect observed by Chopin et al. (1995), though the metabolic alteration producing higher $\mathrm{C}: \mathrm{N}$ ratios did not derive from $\mathrm{N}$ limitation in culture. The temperaturedriven increases in $\mathrm{C}: \mathrm{N}$ ratio suggest a reduction in nutritional quality. The native G. tikvahiae did not show the same temperature dependence of tissue $\mathrm{N}$ and $\mathrm{C}: \mathrm{N}$ ratio, at least over the $20-29^{\circ} \mathrm{C}$ range. The influence of growth temperature on tissue composition of rhodophyes is mixed; on one hand, prior work reported greater tissue $\mathrm{N}$ content at higher culture temperature in two species of Porphyra (Kim et al. 2007), though no consistent influence of temperature on either tissue $\mathrm{N}$ content or C : $\mathrm{N}$ ratio was reported for Palmaria palmata or Chondrus crispus (Corey et al. 2012).

Invasive species are expected to change ecosystem dynamics. In LIS, since G. vermiculophylla is morphologically similar to its congener, G. tikvahiae, the invasion is cryptic, meaning difficult to detect. Cryptic invasions generally lead to underestimation in invasive population size (Saltonstall 2002). This makes early detection and attempts at control or eradication difficult or impossible. The invasion of G. vermiculophylla can have negative effects on other species within the LIS community. Eelgrass Zostera marina L., a key coastal ecosystem engineer, may be negatively impacted by addition of G. vermiculophylla. A Danish study found a negative relationship between $Z$. marina survival and both temperature and presence of G. vermiculophylla (Höffle et al. 2011). Reduced levels of light, oxygen, and nutrients as a result of G. vermiculophylla presence are likely to explain the negative impacts on Z. marina health (Thomsen et al. 2013). Similar effects are likely to be seen within the LIS, contributing to the decline of the already struggling eelgrass (Koch and Beer 1996, Lopez et al. 2014). Mortality of Z. marina would have broadly reaching impacts since eelgrass makes important contributions to the health of the entire LIS ecosystem through increased water quality and nutrient transformation (Lopez et al. 2014), as well as acting as nursery habitat (Bertelli and Unsworth 2014).

The introduction of a non-native alga also has the potential to change community structure as a result of altered patterns of herbivory, a controlling factor of algal distribution (Monteiro et al. 2009). The enemy release hypothesis argues that non-native species are successful in a new ecosystem at least in part because of the lack of control by enemies, including competitors, pathogens, parasites, and predators (Colautti et al. 2004). Grazers native to an environment prefer to eat native plant species over non-native species (Monteiro et al. 2009). Specifically, studies on consumption of G. vermiculophylla in its native habitat and in its non-native habitat have shown herbivore preference for the native (Hammann et al. 
2013), likely tied to the high concentration of toxic prostaglandin $\mathrm{E}_{2}$ in the introduced G. vermiculophylla (Hammann et al. 2016). Low palatability and reduced control of growth by lack of enemies can contribute to the invasive success of G. vermiculophylla as it then does not have to allocate resources to defense or compensate for herbivory. Though results show the LIS strain of G. vermiculophylla growing at similar rates to the LIS native, the low palatability and lack of enemies working in synergy can allow G. vermiculophylla to outcompete G. tikvahiae.

The ability of G. vermiculophylla to respond to stresses in addition to high temperature is not fully known. This invasive seaweed appears to be highly resistant to stressors including desiccation, high and low salinity, and low light; for example, the species can survive several months of darkness in low nutrient conditions (Yokoya et al. 1999, Kim et al. 2016). As most invasive species, G. vermiculophylla possesses generalist characteristics giving the seaweed the ability to succeed in a range of habitats unlike that of its native range. Results show successful growth and concentration of nitrogen in G. vermiculophylla as compared to native G. tikvahiae. The LIS native seaweed will not be able to sustain a healthy population with continued increases in temperature, while the invasive has a higher upper limit of temperature tolerance. Synergism between high stress tolerance, low palatability outside of its native range, and survival in increasing global temperatures will allow G. vermiculophylla to successfully invade the LIS.

\section{ACKNOWLEDGEMENTS}

This study was supported by a grant to CY and JKK from United States-Israel Binational Agricultural Research and Development Fund (BARD; US- 4599-13 R), a grant to CY, JKK and GPK the U.S. EPA Long Island Sound Study's Long Island Sound Futures Fund, New York State Attorney General's Bronx River Watershed Initiative Grant Program, National Fish and Wildlife Foundation (NFWF/Legacy Grant Project IDs: 1401.10.024266 and 8012.08.030370), a grant to CY from Connecticut Sea Grant College Program (R/A-38), a grant to JKK from the National Institute of Fisheries Science (R2017015), Republic of Korea, and Marine Biotechnology program grants to SMB from the Ministry of Ocean Sciences and Fisheries. The Purchase College School of Natural and Social Sciences, and L. Werlinich provided financial support for LG and GPK. CY and JKK would also like to acknowledge NOAA-Ministry of Oceans and Fisheries (MOF) of Korea Joint Project Agree- ment on Integrated Multi-Trophic Aquaculture, through the Joint Coordination Panel for Aquaculture Cooperation for US-Korea.

\section{REFERENCES}

Abreu, M. H., Pereira, R., Buschmann, A. H., Sousa-Pinto, I. \& Yarish, C. 2011a. Nitrogen uptake responses of Gracilaria vermiculophylla (Ohmi) Papenfuss under combined and single addition of nitrate and ammonium. J. Exp. Mar. Biol. Ecol. 407:190-199.

Abreu, M. H., Pereira, R., Sousa-Pinto, I. \& Yarish, C. $2011 b$. Ecophysiological studies of the non-indigenous species Gracilaria vermiculophylla (Rhodophyta) and its abundance patterns in Ria de Aveiro Lagoon, Portugal. Eur. J. Phycol. 46:453-464.

Abreu, M. H., Pereira, R., Yarish, C., Buschmann, A. H. \& Sousa-Pinto, I. 2011c. IMTA with Gracilaria vermiculophylla: productivity and nutrient removal performance of the seaweed in a land-based pilot scale system. Aquaculture 312:77-87.

Anderson, L. W. J. 2007. Control of invasive seaweed. Bot. Mar. 50:418-437.

Bertelli, C. M. \& Unsworth, R. K. F. 2014. Protecting the hand that feeds us: seagrass (Zostera marina) serves as commercial juvenile fish habitat. Mar. Pollut. Bull. 83:425429.

Breeman, A. M. 1988. Relative importance of temperature and other factors in determining geographic boundaries of seaweeds: experimental and phenological evidence. Helgoländer Meeresunters. 42:199-241.

Byers, J. E., Gribben, P. E., Yeager, C. \& Sotka, E. E. 2012. Impacts of an abundant introduced ecosystem engineer within mudflats of the southeastern US coast. Biol. Invasions 14:2587-2600.

Carlton, J. T. 2001. Introduced species in the U.S. coastal waters: environmental impacts and management priorities. Pew Oceans Commission, Arlington, VA, 28 pp.

Chopin, T., Gallant, T. \& Davison, I. 1995. Phosphorus and nitrogen nutrition in Chondrus crispus (Rhodophyta): effects on total phosphorus and nitrogen content, carrageenan production, and photosynthetic pigments and metabolism. J. Phycol. 31:283-293.

Cohen, A. N., Weinstein, A., Emmett, M. A., Lau, W. \& Carlton, J. T. 2001. Investigations into the introduction of nonindigenous marine organisms via the cross-continental trade in marine baitworms. A report for the U.S. Fish and Wildlife Service. June 2001. San Francisco Bay Program. U.S. Fish and Wildlife Service, Sacramento, CA, 29 pp. 
Colautti, R. I., Ricciardi, A., Grigorovich, I. A. \& MacIsaac, H. J. 2004. Is invasion success explained by the enemy release hypothesis? Ecol. Lett. 7:721-733.

Corey, P., Kim, J. K., Garbary, D. J., Prithiviraj, B. \& Duston, J. 2012. Bioremediation potential of Chondrus crispus (Basin Head) and Palmaria palmata: effect of temperature and high nitrate on nutrient removal. J. Appl. Phycol. 24:441-448.

Freshwater, D. W., Montgomery, F., Greene, J. K., Hamner, R. M., Williams, M. \&Whitfield, P. E. 2006. Distribution and identification of an invasive Gracilaria species that is hampering commercial fishing operations in southeastern North Carolina, USA. Biol. Invasions 8:631-637.

Gulbransen, D. J., McGlathery, K. J., Marklund, M., Norris, J. N. \& Gurgel, C. F. D. 2012. Gracilaria vermiculophylla (Rhodophyta, Gracilariales) in the Virginia coastal bays, USA: COX1 analysis reveals high genetic richness of an introduced macroalga. J. Phycol. 48:1278-1283.

Hammann, M., Rempt, M., Pohnert, G., Wang, G., Boo, S. M. \&Weinberger, F. 2016. Increased potential for wound activated production of prostaglandin $\mathrm{E}_{2}$ and related toxic compounds in non-native populations of Gracilaria vermiculophylla. Harmful Algae 51:81-88.

Hammann, M., Wang, G., Rickert, E., Boo, S. M. \& Weinberger, F. 2013. Invasion success of the seaweed Gracilaria vermiculophylla correlates with low palatability. Mar. Ecol. Prog. Ser. 486:93-103.

Höffle, H., Thomsen, M. S. \& Holmer, M. 2011. High mortality of Zostera marina under high temperature regimes but minor effects of the invasive macroalgae Gracilaria vermiculophylla. Estuar. Coast. Shelf Sci. 92:35-46.

Intergovernmental Panel on Climate Change (IPCC). 2014. Climate change 2014 synthesis report summary for policymakers. Available from: https://www.ipcc.ch/pdf/ assessment-report/ar5/syr/AR5_SYR_FINAL_SPM.pdf. Accessed Jul 1, 2016.

Johnson, C. R. \& Chapman, A. R. O. 2007. Seaweed invasions: introduction and scope. Bot. Mar. 50:321-325.

Johnson, R. B., Kim, J. K., Armbruster, L. C. \& Yarish, C. 2014. Nitrogen allocation of Gracilaria tikvahiae grown in urbanized estuaries of Long Island Sound and New York City, USA: a preliminary evaluation of ocean farmed Gracilaria for alternative fish feeds. Algae 29:227-235.

Keser, M., Swenarton, J. T., Vozarik, J. M. \& Foertch, J. F. 2003. Decline in eelgrass (Zostera marina L.) in Long Island Sound near Millstone Point, Connecticut (USA) unrelated to thermal input. J. Sea Res. 49:11-26.

Kim, J. K., Kraemer, G. P., Neefus, C. D., Chung, I. K. \& Yarish, C. 2007. Effects of temperature and ammonium on growth, pigment production and nitrogen uptake by four species of Porphyra (Bangiales, Rhodophyta) native to the New England coast. J. Appl. Phycol. 19:431-440.

Kim, J. K., Kraemer, G. P. \& Yarish, C. 2014. Field scale evaluation of seaweed aquaculture as a nutrient bioextraction strategy in Long Island Sound and the Bronx River Estuary. Aquaculture 433:148-156.

Kim, J. K., Kraemer, G. P. \& Yarish, C. 2015. Use of sugar kelp aquaculture in Long Island Sound and the Bronx River Estuary for nutrient extraction. Mar. Ecol. Prog. Ser. 531:155-166.

Kim, J. K. \& Yarish, C. 2014. Development of a sustainable land-based Gracilaria cultivation system. Algae 29:217225.

Kim, J. K., Yarish, C. \& Pereira, R. 2016. Tolerances to hypoosmotic and temperature stresses in native and invasive species of Gracilaria (Rhodophyta). Phycologia 55:257264.

Kim, S. Y., Weinberger, F. \& Boo, S. M. 2010. Genetic data hint at a common donor region for invasive Atlantic and Pacific populations of Gracilaria vermiculophylla (Gracilariales, Rhodophyta). J. Phycol. 46:1346-1349.

Koch, E. W. \& Beer, S. 1996. Tides, light and the distribution of Zostera marina in Long Island Sound, USA. Aquat. Bot. 53:97-107.

Lewin, J. 1966. Silicon metabolism in diatoms, V. Germanium dioxide, a specific inhibitor of diatom growth. Phycologia 6:1-12.

Lopez, G., Carey, D., Carlton, J., Cerato, R., Dam Guerrero, H., Digiovanni, C., Elphick, C., Frisk, M., Gobler, C., Hice, L., Howell, P., Jordan, A., Lin, S., Liu, S., Lonsdale, D., McEnroe, M., McKown, K., Mcmanus, G., Orson, R., Peterson, B., Pickerell, C., Rozsa, R., Shumway, S., Talmage, S., Taylor, G., Thomas, D., Van Patten, P., Vaudrey, J., Wikfors, G., Yarish, C. \& Zajac, R. 2014. Biology and ecology of Long Island Sound. In Latimer, J. S., Tedesco, M., Swanson, R. L., Yarish, C., Stacey, P. \& Garza, C. (Eds.) Long Island Sound: Prospects for the Urban Sea. Springer Publishers, New York, NY, pp. 285-479.

Lüning, K. 1990. Seaweeds: their environment, biogeography and ecophysiology. Wiley, New York, $527 \mathrm{pp}$.

Monteiro, C. A., Engelen, A. H. \& Santos, R. O. P. 2009. Macroand mesoherbivores prefer native seaweeds over the invasive brown seaweed Sargassum muticum: a potential regulating role on invasions. Mar. Biol. 156:2505-2515.

National Centers for Environmental Information (NOAA). 2015. Water temperature table of the Northern Atlantic Coast. NCEI, Maryland Office. Available from: https:// www.nodc.noaa.gov/dsdt/cwtg/natl.html. Accessed Jul $1,2016$.

Nettleton, J. C., Mathieson, A. C., Thornber, C., Neefus, C. D. 
\& Yarish, C. 2013. Introduction of Gracilaria vermiculophylla (Rhodophyta, Gracilariales) to New England, USA: estimated arrival times and current distribution. Rhodora 115:28-41.

Sakai, A. K., Allendorf, F. W., Holt, J. S., Lodge, D. M., Molofsky, J., With, K. A., Baughman, S., Cabin, R. J., Cohen, J. E., Ellstrand, N. C., McCauley, D. E., O’Neil, P., Parker, I. M., Thompson, J. N. \&Weller, S. G. 2001. The population biology of invasive species. Annu. Rev. Ecol. Syst. 32:305332.

Saltonstall, K. 2002. Cryptic invasion by a non-native genotype of the common reed, Phragmites australis, into North America. Proc. Natl. Acad. Sci. U. S. A. 99:24452449 .

Schneider, C. W., Suyemoto, M. M. \& Yarish, C. 1979. An annotated checklist of Connecticut seaweeds. Conn. Geol. Nat. Hist. Surv. Bull. 108:1-20.

Stachowicz, J. J., Terwin, J. R., Whitlatch, R. B. \& Osman, R. W. 2002. Linking climate change and biological invasions: ocean warming facilitates nonindigenous species invasions. Proc. Natl. Acad. Sci. U. S. A. 99:15497-15500.

Stachowicz, J. J., Whitlatch, R. B. \& Osman, R. W. 1999. Species diversity and invasion resistance in a marine ecosystem. Science 286:1577-1979.

Thomsen, M. S., Stæhr, P. A., Nejrup, L. \& Schiel, D. R. 2013. Effects of the invasive macroalgae Gracilaria vermiculophylla on two co-occurring foundation species and associated invertebrates. Aquat. Invasions 8:133-145.
Tseng, C. K. \& Xia, B. -M. 1999. On the Gracilaria in the western Pacific and the southeastern Asia region. Bot. Mar. 42:209-218.

Weinberger, F., Hammann, M., Pohnert, G., Wang, G. G. \& Boo, S. M. 2013. Successful invaders are better defended: the example of Gracilaria vermiculophylla. Phycologia 52(4 Suppl.):1-119.

Williams, S. L. \& Grosholz, E. D. 2008. The invasive species challenge in estuarine and coastal environments: marrying management and science. Estuaries Coast. 31:320.

Yarish, C., Breeman, A. M. \& van den Hoek, C. 1984. Temperature, light, and photoperiod responses of some northeast American and west European endemic rhodophytes in relation to their geographic distribution. Helgoländer Meeresunters. 38:273-304.

Yarish, C., Breeman, A. M. \& van den Hoek, C. 1986. Survival strategies and temperature responses of seaweeds belonging to different biogeographic distribution groups. Bot. Mar. 29:215-230.

Yarish, C. \& Edwards, P. 1982. A field and cultural investigation of the horizontal and seasonal distribution of estuarine red algae of New Jersey. Phycologia 21:112-124.

Yokoya, N. S., Kakita, H., Obika, H. \& Kitamura, T. 1999. Effects of environmental factors and plant growth regulators on growth of the red alga Gracilaria vermiculophylla from Shikoku Island, Japan. Hydrobiologia 398:339-347. 